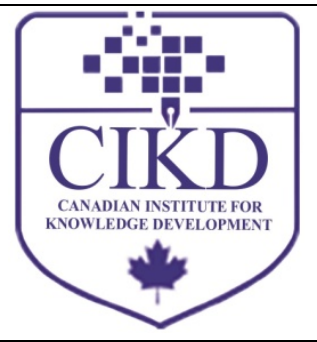

\title{
Determining the Factors Affecting Individual Investors' Behaviours
}

\author{
Sevilay USLU DIVANOĞLU ${ }^{1}$, Dr. Haşim BAĞCI ${ }^{2 *}$ \\ ${ }^{1}$ Assistant Professor, Aksaray University, Business Administration Department, Marketing Program \\ ${ }^{2}$ Aksaray University, Business Administration Department, Finance Program
}

\section{Keywords:}

Behavioral Finance,

Individual Investors,

Investment Decisions and

Socio-economic Factors

\section{Received}

09 May 2018

Received in revised form

11 August 2018

Accepted

24 August 2018

Correspondence:

hasimbagci1907@hotmail.com

\section{Abstract}

Behavioral finance is precisely non-rational behavior of market investors. Behavioral finance theory shows that investors make investment decisions rationally, by intermittent change from the past and that investment decisions can be taken under the influence of some psychological factors. This theory shows how human behaviors are effective in the functioning of investment decisions and that investment decisions can be made in nonrational behaviors. People are determined to invest under the influence of emotions and personal intuitions with models based on rational behavior and investment behaviors. Whether individuals are rational in the economic decision-making process is one of the key points of debate and it seems quite complex to be able to demonstrate this. This study will focus on individuals (investors), one of the economic decision makers. Socio-economic factors, as well as psychological factors, influence the risk that investors perceive in the decision-making process of individual investors. The purpose of this study is to identify stimuli that affect individual investors' drivers of financial investment decisions and to consider it in terms of behavioral finance. For this purpose, an individual investor questionnaire has been determined in the field which has previously been validated and reliable. This questionnaire was applied to 200 employees working in private and public banks operating in Aksaray and 177 people were provided feedback. In the case of Aksaray, it has been determined which stimulants are under the influence of predictions, estimates, emotions, personal intuitions, psychological and sociological behaviors of investment decision-making individuals.

Within the past 20-30 years, the scientists investigating financial markets have tried to explain the processes in financial markets with behavioral biases moving away from the influence of 
rational theories. This is because individual investors' investment behaviors are affected by psychological biases. Kahneman is the person who made the biggest leap forward in behavioral finance in 1979 and made it a big step forward. Kahneman, the most important name in the field of behavioral finance, has made it clear that investors are not rational and that psychological factors dominate investor decisions. In addition, many studies have been published that demonstrate investors cannot make rational decisions on uncertainty and risk situations (Cornicello, 2004, p. 23; Nofsinger, 2005, p. 1; Perşembe, 2001, p. 17; Tufan, 2006, p. 11).

Investors and individuals are considered to be rational beings trying to increase their personal interests (Shleifer, 2004, pp. 1-3). As for behavioral finance, it emerged as opposed to rational decision-making models and adopted a rational or limited rational approach. In other words, classical finance conception assumes that market players make logical decisions, while behavioral financiers argue that the opposite is true, that markets act on investor psychology and that investors have some psychological concepts such as biases and overconfidence in decision-making stages (Keklik, 2011, p. 1).

Behavioral finance examines psychological and sociological factors that affect decisions when individuals making investment decisions. It is impossible for the individual investor to act rationally, but it is assumed that there is a continuous rationality in traditional financial understanding. When it comes to behavioral finance, it is expressed that people are in many souls such as sadness and rejoicing, and the level of decision will change according to these moods. It was reported that traditional financiers are rational but behavioral finance is normal. This proves that there are factors that affect people's behavior (Gazel, 2014, pp. 5-6).

It is known that the degree to which individuals perceive risk in a subjective way affects investment decisions. The degree of risk perception or risk breach varies depending on the individual person, the amount of investment made and the amount of return on investment. In addition, the risk taking levels of individuals are affected by uncertainty and the consequences of the investment decision.

It depends on the degree of preference of consumers to carry out and sustain the vital activities of the enterprises. The investment decisions of the consumers providing the continuity of the goods and services producing enterprises are also important for the enterprises providing banking services. The individual investor, who is the basic unit in the investment process, is actually the consumer buying the service. Consumers dedicate a portion of the income they receive as a result of their work in order to meet their needs, the other part makes savings. They direct the economic values and save investment instruments for different purposes. In other words, they want to obtain a satisfactory amount of return from the savings they incur on investment vehicles.

The purpose of this study is to determine the factors that are influenced by individual investors in determining investment decisions and the factors that influence their decisions. In order to realize this aim, 177 questionnaires were applied to the personnel working in private and public banks operating in Aksaray city center. The questionnaire on the individual investor perception of the bank staff includes some behavioral finance based questions. 


\section{Literature Review}

Behaviorism was first introduced by John D. Watson in 1913 and developed by B. F. Skinner and adapted to psychology. The roots of the behavioralism theory are revealed in the work of Adam Smith. However, in the twentieth century, psychology was rejected within the scope of finance, and the studies made were not appreciated. Until recent years, investors have assumed that they have always acted rationally according to Eugene Fama's (1970) Nobel Prize for "Effective Market Hypothesis"; but Daniel Kahneman, Richard Thaler and Amos Tversky refuted this theory and found that psychology had a direct impact on investment decisions. Kahneman and Tversky (1979) have introduced a new perspective on finance literature with their work. Kahneman (2002) received Nobel prizes for his work "Thinking, Fast and Slow" and Thaler and Sunstein (2017) for "Nudge" (Royal Swedish Academy of Sciences, 2002, pp. 1-12; Tufan, 2006. P. 29). In this way, behavioral finance is the science of classical economics and finance, the composition of psychology and decision science, the exploration of the causes of anomalies, the measurement of psychology's influence on decision making, and the mistakes that investors make in decision making (Fuller, 1998, p. 1; Shefrin, 2001). Behavioral finance can be defined as the science that investigates the psychology of investors' behavior and its impact on the market (Sezer, 2013, p. 63). In other words, behavioral finance argues that psychology is a direct influence on the investor's decisions and examines the buying and selling behaviors of individual investors to reveal this effect (Y1ldirım, 2017, p. 40).

The framework of studies done in the field of behavioral finance is shaped around cognitive and emotional tendencies. These studies suggest that individuals want to rationally avoid riskier investment decisions, optimize their preferences and diversify portfolios, but do not implement them in practice. Psychological prejudices including heuristics, cognitive biases and emotional factors are shown as the main reasons for this. In other words, investment decisions are based on intuition and feelings rather than being rational (Döm, 2003, p. 43).

Nagy and Obenberger (1994) investigated the relationship between retail investor behavior and economic and demographic variables in their research. This review was made by online questionnaire. Surveys were sent via 500 experienced shareholders emails obtained from a trusted and proprietary source and participated in a financial marketing research. Of the 500 surveys, $137(27.4 \%)$ responded in a usable way. Participants were asked to rate 34 variables that had the potential to influence equity investment decisions. These variables address traditional issues such as risk, diversification, as well as current issues such as the importance of firm ethics and firm commitment to the environment. The variables were subjected to factor analysis according to the answers given. As a result, at least seven homogeneous variable groups affecting individual investor behavior have been identified. These groups are neutral information, accounting information, traditional or individual financial needs, social interest, friend recommendation, and individual image / corporate image conflict.

Usul, Bekçi, and Eroğlu (2002) examined the factors affecting investors' buying and selling of stocks. In their study, it was determined that the factors that investors were most affected by socio-economic variables when buying stocks. It is stated that socio-economic factors refer to personal and environmental changes. Other results are as follows: share investment was $20 \%$ of all investments, the youngest investors were the most investors, the share holding time increased as the income level increased, the elderly investors were quick to remove 
investments and take no risks, women were less likely to take risks, education level and risk taking rate increased as income increased.

Ede (2007) investigated behavioral trends for individual investor behavior and intended to determine what changes individual investors have, both in terms of demographic and some distinctive traits. As a result, most individual investors were found to be under systematic errors under biases and exhibit non-rational behavior.

Kahyaoğlu (2011) measured the effects of gender on investment decisions. In making this measure, the role of gender on psychological and emotional factors was identified. During the study, 31 individual investors in Stock Exchange Istanbul benefited from the share purchase and sale data they had made between 2007-2009. As a result of the study, it has been revealed that male and female investors behave quite differently while making investment decisions. The most important of these differences are as more frequent transactions were made by men, more consistent transactions were made by men, and there was less diversification of women's portfolios.

Saraç and Kahyaoğlu (2011) examined the demographic and socio-economic factors affecting the risk perception of individual investors engaged in buying and selling transactions in Stock Exchange Istanbul. As a result of the study, it was determined that the risk perception changed according to the demographic and socio-economic factors. The results of this change are as follows: the elderly individuals are riskier than the younger ones and the retirees are more at risk than the workers, the women are less risky than the men, the income-risk relationship is both positive and negative and the level of education is higher than the graduates of high school graduates as they take more risks but the risk taking level of university graduates is lower than those of graduate and doctoral graduates.

Demir, Akçakanat, and Songur (2011) investigated the impact of psychologists' investment decisions on individuals investing in stocks in Istanbul Stock Exchange. The study was carried out by face-to-face questionnaires and random sample method of 270 individual investors in Lake District (Isparta, Burdur, \& Antalya) between 01.11.2009-10.12.2009. As a result of the research, it was found that some psychological factors affected investor decisions. Investors were influenced by factors such as the media, friend environment, and they were able to demonstrate herd behavior and failed to make rational decisions. As a result, anomalies were formed in the market.

Hon (2012), in his work, investigated the behavior of small investors operating in derivative markets in Hong Kong. The time period of the study is between 2011-2012. This is why the study focuses on the behavior of small investors before and after the global crisis period. Data were collected from 524 participants by questionnaire method. Exploratory factor analysis was used to analyze the data. This led to the conclusion that the behavior of small investors in Hong Kong derivative markets consistently demonstrated the increasing importance of return performance, reference group and personal history.

Jureviciene, Bikas and Gausiene (2012) examined investor behavior during the economic crisis in Lithuania. As a result of the surveys, Lithuanians were aware of the necessity of saving but they were found not to make long term investments and retirement plans. Lithuanians have opted for short-term investments and were not able to think much of their future for too long by living at the moment. 
Hoffmann, Post and Pennings (2013) examined investor perceptions and behavior during the financial crisis period. By combining monthly survey data with matching business records, it is measured how individual investor perceptions change and how trading and risk taking behaviors are affected during the 2008-2009 financial crisis. It appears that investor perceptions fluctuate significantly during the crisis, and there is less deviation from risk tolerance and return expectations than risk expectations. In the worst periods of the crisis, investors' expectation of return and risk perceptions increased as risk tolerance decreased. Towards the end of the crisis, investor perceptions improved. Significant fluctuations in buying and selling and risk taking behavior resulting from changes in investor perceptions were observed. As a result, it was found that individual investors continue to actively trade but do not risk investment portfolios during the crisis.

Gümüş, Koç and Agalarova (2013), in their work, have found psychological and demographic factors that affect the investment decisions of individual investors in Turkey and Azerbaijan. This study was conducted in 384 persons in both countries by face-to-face survey method. As a result of the work, the level of income and education, marital status, age and gender were found to influence investment decisions.

Lebbe and Rauf (2014) studied the psychological prejudices that distort the behavior of investors in Bahrain before and after the 2007-2008 economic crises. The main psychological biases investigated are overconfidence, representativeness, harm avoidance, regret and group behavior. Five interviews with Bahrain executives have been conducted to decide where and with which group the investors will be conducting the questionnaires. The study has shown that psychological biases affect investors before and during the crisis and lead to massive losses when the crisis intensifies. As a result of the research, a positive relationship was found between regret and group behavior, but since the investors were more cautious after the crisis, this relationship was removed.

İslamoğlu, Apan and Ayvalı (2015) examined individual investor profiles and investor preferences in Bartın. This research was conducted by 215 employees at the bank branch in face-to-face survey method and at a time period of 3 weeks from June 16 to July 5 . As a result of the study, it was determined that the factors that enable Bartın investors to direct investment decisions are experience, income level and expert opinions. It is also emphasized that investors are attempting to diversify their portfolios according to financial stability and that their confidence levels are high.

Nyamute, Lishenga and Olko (2015) tried to determine the relationship between the behavior of the 385 stock investors trading on the Nairobi Stock Exchange and the performance of the portfolios they formed. The relationship between investor behavior and portfolio performance was tested using multiple regression analysis. The overall model was statistically significant. While investor behavior had a positive effect on portfolio performance, it showed that excessive confidence had a negative effect on performance. From the results, behavioral biases had a noticeable effect on the outcome of trading activities. It was emphasized that stock market players could use these findings to understand market dynamics and to combine behavioral factors when analyzing the performance of capital markets.

In Bodur's (2016) study, the factors affecting the behavior of investors have been examined within the framework of overconfidence dimension. Overconfidence was found to be effective 
on investor behavior. The results also indicated that married men have the highest level of knowledge about the markets; male investors were more likely to have overconfidence than female investors, male investors preferred risky investments, male investors revised their investments more often and trade more often, single men were the most preferred group for risky investments.

Doğan, Yildız and Topal (2016) measured whether their investment preferences change depending on their demographic characteristics. This measurement was made for 268 personnel of banks in Hatay, Kocaeli, Denizli, Eskişehir, Aydın and Mersin provinces. As a result of this analysis, it was found that demographics influenced investment decisions.

Kesbiç and Yiğit (2016) measured the risk trends according to income, saving rate and demographic characteristics of 387 individual investors in Manisa province. Significant differences in risk perception have been identified as a result of this measurement. These differences are shown by comparing the average of Manisa and Turkey. The average savings rate reached $16.1 \%$ in Manisa, while Turkey average reached $7.3 \%$ according to TurkStat data. Regarding preferred investment tools, individuals in Manisa preferred gold by the rate of $31.4 \%$, and this rate is above the Turkey average (2.1\%). For Manisa, rate of preferring stocks $(7.2 \%)$ was very close to Turkey average (5.1\%). In the preferring investment of individuals in Manisa, A and B type investment fund with a total share of about $6 \%$ and again it is very close to Turkey average (7.9\%). Repo rate preference was .3\% both in Turkey and Manisa. In the total public and private debt securities, the average was $2.6 \%$ in Turkey and $1.7 \%$ in Manisa. Referring to the preferred foreign currency rate, the average was $21.7 \%$ in Turkey and $12 \%$ in Manisa.

Yeşildağ, Atasever, Kuduz and Coşkun (2017) analyzed the stock investor profile of Afyon and Kütahya cities and the factors affecting investment decisions. As a result of the research, it was determined that investors were not rational and did not have enough knowledge about the stock market. In addition, age, gender, occupation, educational status, number of households and income were found to be effective in investment decisions.

\section{The Factors Affecting the Individual's Investment Decision}

An individual investor can be defined as individuals who do not allocate all of their revenues to consumption expenditures and partly invest in the future, and act on their behalf and account at the market (Temizel, Sarıkaya, \& Bayram, 2010, pp. 1-20). According to another definition, an individual investor is an investor who trades on his own behalf and accounts for a small amount of transactions, and who tries to manage his own funds with little or no professional support (Karan, 2004, p. 699). It can be shown that individual investors are generally investors who invest in their own names and accounts, whose transaction amounts are relatively small, and that they are affected by a number of personal, financial and environmental factors in the investment decisions of individual investors (Elmas, 2010, p. 8).

The fact that the changes in the investor profile, which are effective on the financial markets, is becoming a factor to consider which is increasing every day (Saraç \& Kahyaoğlu, 2011, p. 136). As individual investors make investment decisions, it is necessary to analyze and evaluate which factors are influenced by them. Individual investors are under the influence of three main factors, personal, financial and environmental, while making investment decisions. 
The first of these factors are personal factors such as having adequate knowledge and time of investors, age, gender, health status, income level, life style, anticipation and psychological status. The second factor is financial factors such as the protection of the existing capital in the hands of the investors, the increase in the value of the capital and the desire to obtain continuous income. Environmental factors, which are the third factor, are considered the social and cultural situation in which investors are involved, reference group, group and family relations (Özaltın, Ersoy, \& Bekçi, 2015, pp. 402-404).

\section{Personal Factors}

Personality is the characteristic integration of behavior patterns, interests and tendencies, talents and orientations. As personality traits are important from a behavioral point of view, these personality traits also become important in terms of finance in the outcome of the anticipation of the actions taken in investment decisions. Some investors take more risk to get more returns while others choose less risky investments because they are afraid of losing (Armağan, 2007, p. 46; Tufan, 2008, p. 45).

The age of individual investors is an important factor. It is possible to assess risk and return and return preferences by looking at the age of the person. Age is one of the most widely used criteria for dividing and classifying investors into financial risk categories. While older investors are generally classified as low investment risk groups, younger investors are classified as high investment risk groups (Anbar \& Eker, 2009, p. 136; Barak, 2008, p. 31). Investors with high levels of income can readily accept risky investments relative to investors with lower incomes. In other words, as age and income increase, we can say that investors' confidence in themselves and their investments is also increasing.

Given the assumption that women's risk perception is higher than that of men in terms of the effect of gender on investment decisions, it is thought that there may be some differences between male and female investors in terms of the level of psychological factors affecting risk perception (Kahyaoğlu, 2011, p. 33). Dwyer, Gilkeson, and List (2002) found that the level of knowledge about financial markets and investments weakened the effect of gender on risk taking, and that women had lower financial risk tolerance than men, partly explained by the level of financial information.

While an individual with a high level of education saves investment decisions by analyzing and analyzing more, an individual with low income might save in more conservative way than those with high incomes. The statutes, powers and beliefs of people in society are largely determined by their level of education. For this reason, education, lifestyle and income level will affect investor behavior (Aksulu, 1993, pp. 16-18).

In addition, studies on whether marital status has an effect on financial risk perception have resulted in different results. Some studies have found that married people have more financial risk tolerance (Anbar \& Eker, 2009, p. 138), while some others found that bachelors have more financial risk tolerance than married ones.

\section{Financial Factors}

The financial factors that are effective in investing the deposits of individuals in their hands can be listed as cash flow, risk, liquidity, return ratios and investment duration (Ayval1, 2014, p. 
50). Savers are constantly refraining from inflation while investing. Because even if inflation causes an increase in the book value of the assets, this increase will not cause the equity price of the entity to increase. On the contrary, it may cause stock prices to fall (Akgün, 1996, p. 265). Saving holders value inflation and interest rates in their economic forecasts and for this purpose they direct their investments into investment tools that will protect their savings from alternative investment tools (Schaof, 1993, pp. 100-101). For example, liquidity reflects the ability of an investment to be turned around at low costs and quickly. When assessed in this sense, it is clear that a more cash asset will be more attractive and therefore the amount demanded will be higher as other things are fixed (Mishkin, 2010, p. 93).

Individual investors, in order to increase the value of their investments, direct their investments to areas of higher value or income that exceed the inflation rate. In doing so, they try to choose the most suitable one among alternative investment instruments. An important factor affecting investment objectives is that individual investors are also in constant demand for a certain income. Therefore, the maximum income and assurance factors for individual investors gain weight (Usul et al., 2002, p. 140).

\section{Environmental Factors}

Environmental factors are groups of socio-cultural environment, close environment, family and other environmental impacts that are affected by investors' investments. Individuals' attitudes and thoughts are largely influenced by the cultures they live in. In other words, the sociocultural situation of the individual also affects the decision-making process. Because individual investors do not have enough knowledge about investment instruments, they want to get the approval and thought of the decision makers. Naturally, these people are usually family members (Usul et al., 2002). Since the owner of the savings also lives in a group or family, the influence of this group or family cannot be ignored in the decisions making. Because individuals feel insecure that they have the wrong idea of making a decision when they are alone in the process of deciding on a topic, they need the approval of the group or the family.

The characteristics of individual investors in terms of risk perception are influential on investment decision-making. The investor describes the risk as losing money or doing something uncomfortable. They perceive negative news about a vehicle; they are not familiar with at a high risk level. Investors think that by investing in popular tools that everyone is interested in, they can reduce the risk. Investors tend to mix up past and future potential risks (Karan, 2004, p. 699).

Reference groups are one of the environmental factors that affect the behavior of individuals. Reference groups are defined as social groups that are important to the individual and shape the attitudes and behaviors of the individual. According to a study done, it was determined that $80 \%$ of the purchasing decisions of the individual were realized by being influenced by someone else's direct recommendation (Hsu et al., 2006, p. 474). Individual investors are affected by the groups they are in when they make investment decisions. This is exemplified by the fact that the recommendations of those who have invested in the securities exchange for years have been taken seriously and taken as a reference. 


\section{A Study on Individual Investors 'Behavior}

The study includes evaluations of the results of a survey on bank employees in order to determine the relationship between the psychological tendencies of individual investors and investment behaviors. In order to examine the preferences and profile of individual investors, the bank employees were asked about personal and social situations of individual investors, investment preferences and information levels and general factors. In this direction, methodology and analysis about empirical analysis involving Aksaray province example were made and the results were explained.

\section{Objectives and Research Methodology}

The present study aims to explain the relationship between personal circumstances of individual investors, social statues, investment preferences and knowledge levels and general factors affecting the investment decision and to reveal the individual investor profile in Aksaray in this frame. In the context of determining investment preferences of individual investors working with private and public banks in Aksaray, the level of knowledge in finance, the participation ratings of financial markets, the follow-up of investments, the term preferences in financial investments and the general factors affecting the investment decision were examined based on the perceptions of the employees of the bank.

Within the scope of the research, a survey form has been prepared to reveal general issues such as how individual investors make investment decisions, how they make decisions and what factors are affected. This questionnaire was carried out in order to reveal the perception of individual investors about the personnel working in public and private banks operating in Aksaray city center. The survey was carried out between 1 February and 1 March 2018 by communicating with bank personnel in Aksaray. Descriptive statistics, cross tables and independent sample T-test were used in statistical methods in the analysis of the data obtained by the questionnaire. The study used random sampling method.

This research was conducted in order to measure the perceptions of individual investors who work in banks in Aksaray province and communicate with individual investors. In addition, discrimination of individual investor perceptions of private and public bank employees is another important factor that makes this research important. This study is thought to contribute to the literature.

\section{Research Hypotheses}

The research has a main hypothesis and three sub hypotheses. Basic hypothesis is:

$\mathbf{H}_{1}$ : According to the perceptions of the bank employees, the average of the sub- dimensions of the factors affecting the individual investment decision differs according to the sector (private-public) in which the bank operates.

Based on this basic hypothesis, 3 sub-hypotheses have been identified. These hypotheses are:

$\mathbf{H}_{1 \mathbf{a}}$ : According to the perceptions of bank employees, the average of the personal and social situation of investors differs according to the sector in which the bank operates.

$\mathbf{H}_{1 \mathbf{b}}$ : According to the perceptions of bank employees, the average of the investment preferences and knowledge of investors differs according to the sector in which the bank operates. 
$\mathbf{H}_{1 \mathbf{c}}$ : According to the perceptions of bank employees, the average of the general factors which affect the investment decisions of investors differs according to the sector in which the bank operates.

\section{Results}

There are 177 bank employees who participated in this study. Demographic characteristics of these personnel are shown in Table 1.

Table 1

Participant Features

\begin{tabular}{llll}
\hline Demographic Features & & Frequency & Percent \\
\hline \multirow{2}{*}{ Sex } & Male & 117 & 66.1 \\
& Female & 60 & 33.9 \\
Age & $21-30$ & 67 & 37.9 \\
& $31-40$ & 93 & 52.5 \\
Marital Status & $41-50$ & 16 & 9 \\
& $51-60$ & 1 & 0.6 \\
Educational Status & Married & 126 & 71.2 \\
& Single & 50 & 28.2 \\
& High School & 12 & 6.8 \\
& Associate degree & Undergraduate & 45.4 \\
Job Experience & Postgraduate & 45 & 58.2 \\
& $0-5$ years & 103 & 9.6 \\
& 6-10 years & 17 & 35 \\
Working Bank & $11-15$ years & 62 & 35 \\
& $15-20$ years & 62 & 18.6 \\
Investment Control Frequency & 21+ & 33 & 7.9 \\
& Private & 14 & 3.4 \\
& Government & 6 & 61 \\
& Every day & 108 & 39 \\
\hline
\end{tabular}

As shown in Table 1, the majority of the employees were male (66.1\%), the age group was predominantly between the ages of 31-40 (52.5\%), most of the participants were married $(71.2 \%)$, most participant were graduated $(58.2 \%)$ in terms of education status, $35 \%$ of employees had $0-5$ years and 6-10 years of work experience, $61 \%$ of the participants work in the private bank and investors control their investments with $29.9 \%$ in irregular and indefinite way about control frequency according to bank staff.

Factors affecting the decision of the bank personnel participating in the study to choose investment instruments related to investor perception are presented in Table 2. 
Table 2

Factors Affecting Investment Preferences

\begin{tabular}{lll}
\hline Factors & Frequency & Percent \\
\hline Return Rate & 75 & 42.4 \\
Risk Level & 49 & 27.7 \\
Divesification & 30 & 16.9 \\
Habits & 24 & 13.6 \\
Ease of Access & 28 & 15.8 \\
Awareness & 21 & 11.9 \\
\hline
\end{tabular}

As presented in Table 2, the most influential factor in investment choice is the rate of return with $42 \%$. The most noticeable factor for investors after the rate of return is the risk level with $27.7 \%$. The factor that is least important for investors and has little effect when making a choice is the awareness factor. The investors' preferences are based on the risk and return rate of investors, but the result is that investors do not care about their awareness. Table 3 shows which sources of information investors use when making investment preferences.

Table 3

Investment Information Sources

\begin{tabular}{lll}
\hline Source Types & Frequency & Percent \\
\hline Analysis and Reports & 41 & 23.2 \\
Newspapers and Magazines & 19 & 10.7 \\
Economy Programs & 42 & 23.7 \\
Company Reports & 24 & 13.6 \\
Friend Suggestions & 23 & 13 \\
Individual Evaluation & 80 & 45.2 \\
Taken Tips & 15 & 8.5 \\
Corporate Internet Sites Related to Stock Exchange & 30 & 16.9 \\
Forum Sites & 15 & 8.5 \\
\hline
\end{tabular}

According to the investors' information sources shown in Table 3, the investors predominantly come out with their own knowledge, skills and evaluations (45.2\%) followed by economic programs $(23.7 \%)$ and analysis and reports $(23.2 \%)$. It is seen that the least preferred source of information for investors is the forum sites and the picks taken at $8.5 \%$. It indicates that investors are most confident when collecting information in order to invest preference and do not trust the information obtained from the information on forum sites.

Factors affecting the choice of investment instrument and the sources of information used vary according to public and private banks. This differentiation has been analyzed through cross tabulation. The change in investment preference in public and private banks is shown in Table 4. 
Table 4

Factors Affecting Investment Decision in Public Banks and Private Banks

\begin{tabular}{lcc}
\hline Factors & Private Banks & Public Banks \\
\hline Return Rate & 53 & 22 \\
Risk Level & 31 & 18 \\
Divesification & 19 & 11 \\
Habits & 14 & 10 \\
Ease of Access & 14 & 14 \\
Awareness & 6 & 15 \\
\hline
\end{tabular}

As shown in Table 4, it is the factor rate of return which has the most effect on investment choice in terms of private banks and the least influential factor is the awareness, while in public banks the most influential factor is the rate of return and the least influential factor is the habits. In both public and private banks, the risk level seems to be important at the second level in influencing the investment choice. It was determined that factors affecting investment decisions differ from public banks and private banks and that each factor does not have the same effect on each bank. For this reason, information sources in public and private banks were also examined, as displayed in Table 5.

Table 5

Diversity of Information Sources in Public Banks and Private Banks

\begin{tabular}{lcc}
\hline Information Sources & Private Banks & Public Banks \\
\hline Analysis and Reports & 28 & 13 \\
Newspapers and Magazines & 14 & 5 \\
Economy Programs & 26 & 16 \\
Company Reports & 15 & 9 \\
Friend Suggestions & 16 & 7 \\
Individual Evaluation & 44 & 36 \\
Taken Tips & 8 & 7 \\
Corporate Internet Sites Related to Stock Exchange & 17 & 13 \\
Forum Sites & 10 & 5 \\
\hline
\end{tabular}

Table 5 shows the information sources in the banks, which vary according to the sector in which the bank operates. The most used information sources in private banks are the individual evaluations while the least benefited information sources are the received tips. Public banks also benefited the most from individual evaluations, but at least newspapers, magazines and forum sites were used. It is indicated that the information sources used in this Table vary according to the public and private banks and the number of people who use each information source in each bank has been changed.

The scale employed in this study was taken from Ayvalı's (2014) and Bodur's (2016) study and its validity and reliability were approved. The reliability of the scale was checked by applying a Cronbach's Alpha coefficient. According to the results of the reliability analysis, Cronbach's Alpha coefficient was measured for 21 observation values. As a result of this measurement, the reliability of the scale depending on the alpha coefficient is interpreted as follows (Kalayci, 2010, p. 405): 
If $0 \leq$ Alpha $<.40$, the scale is not reliable. It must be rearranged.

If $.40 \leq$ Alpha $<.60$, the reliability of the scale is low. It must be rearranged or modified.

If $.60 \leq$ Alpha $<.80$, the scale is highly reliable.

If $.80 \leq$ Alpha $<1.00$, the scale is a reliable measure at high level.

In this study, Cronbach's Alpha coefficient was calculated as .77 which shows that the scale is very reliable.

The Independent Sample T-test was used to test the baseline and sub hypotheses of the study. Levene's test was first applied to determine the variance between the groups. According to the Levene's test results, the variance between the groups of "personal-social situations and investment preferences and knowledge levels" is homogenized from the sub-dimensions. Since the "general factors" were not homogeneous among the groups, the second sample was used as the Independent Sample T- test results. The T-test results are shown in Table 6.

Table 6

Independent Samples T Test

Levene's Test for

Equality of Variances t-test for Equality of Means

\begin{tabular}{|c|c|c|c|c|c|c|}
\hline & & $F$ & $p$ & $t$ & $d f$ & $p$ (2-tailed) \\
\hline Personal and Social & Equal variances assumed & .48 & .48 & 1.18 & 175 & .23 \\
\hline Situations & Equal variances not assumed & & & 1.23 & 164.858 & .21 \\
\hline \multirow{2}{*}{ Basic Knowledge Levels } & Equal variances assumed & 2.16 & .14 & -3.34 & 175 & .001 \\
\hline & Equal variances not assumed & & & -3.25 & 133.071 & .001 \\
\hline \multirow[t]{2}{*}{ General Factors } & Equal variances assumed & 4.38 & .03 & .08 & 175 & .93 \\
\hline & Equal variances not assumed & & & .08 & 174.993 & .93 \\
\hline
\end{tabular}

$\mathrm{H}_{1 \mathrm{~b}}$ hypothesis is accepted because the significance value is $.001 \leq .05$. The sub-dimensions of the scale used to determine the profile of the individual investor correspond to a value of 3.34 of the variable "investment preference information levels". This means that according to the perceptions of bank employees, investors' investment preferences and the average level of knowledge differ according to the sector in which the bank operates. $\mathrm{H} 1 \mathrm{a}$ and $\mathrm{H}_{1 c}$ hypotheses were rejected because there was no statistically significant difference between the "personal and social situations" and "general factors" variables in the subscales used. Table 7 shows the differences between the groups.

Table 7

Group Statistics

\begin{tabular}{|c|c|c|c|c|}
\hline & Working Bank & $n$ & $M$ & $S D$ \\
\hline \multirow[t]{2}{*}{ Personal and Social Situations } & Private & 108 & 3.73 & .51 \\
\hline & Public & 69 & 3.64 & .42 \\
\hline \multirow[t]{2}{*}{ Basic Knowledge Levels } & Private & 108 & 3.29 & .51 \\
\hline & Public & 69 & 3.57 & .57 \\
\hline \multirow[t]{2}{*}{ General Factors } & Private & 108 & 3.99 & .67 \\
\hline & Public & 69 & 3.98 & .43 \\
\hline
\end{tabular}

The sub-dimensions of personal and social situations and general factor variables do not differ according to the sector in which the bank operates. This is evidenced by the fact that the average of both private and public banks are close to each other. However, investment preferences and information level averages are higher in public banks (3.57) than in private banks (3.29). For this reason, the statistical differences between investment preferences and 
knowledge levels, investment preferences and knowledge levels are different in public and private banks.

\section{Conclusion}

Individual investors are individuals operating in the financial markets. Individual investors need to be well analyzed and assessed on what factors they are influencing when making investment decisions. The movements of individual investors are sometimes caused by fluctuations in financial markets that are not meaningful. In the behavioral finance perspective, investors are not only influenced by economic and financial indicators while making their decisions. Investors, acting on the basis of past experiences, are influenced by some psychological factors according to the state of perception and shape. Individual investors' personal and social situations, investment preferences and level of knowledge and general factors (state policies, economic stability, income levels \& experience) affect investment decisions.

The results of this study revealed that minimizing the risk of return, risk exposure and diversification is the most important variable in choosing investment instruments and that individual sources of information gathered during these elections come with individual evaluations, analyzes and reports and economic programs. It has been determined that the rate of return and the level of risk of these factors are the most important factors in both banking sectors in terms of public and private banks and in terms of the sources of information gathered. It was also found that individual evaluations have the first priority level. In addition, the scale used in this study was tested for reliability and proved to be highly reliable with a rating of $77 \%$. Factors considered to affect the investment decision in this study are three subgroups: personal and social situations, basic knowledge levels and general factors. As a result of the independent sample t-test, it was determined that these factors did not differ between the groups. As a result of the analysis, it was determined that investment preferences and knowledge levels of investors differ in private banks and public banks but that the general factors affecting investors' personal and social situations and investment decisions do not differ when considering sectors of banks.

Further research can be conducted by expanding the number of surveys and increasing the number of cities. When the number of working provinces is increased and the factors affecting the investment preferences on a regional basis are compared, the investment portfolio can be reviewed with this result. Moreover, this study can be done among the banks in the world to compare the investment preferences between the countries and the factors affecting these preferences. Thus, the investment profile of all the countries in the world can be revealed. Finally, it is proposed that all the potential investors in the world should be made online to cover the universal dimension of the work rather than banks.

\section{References}

Akgün, A. (1996). Enflasyonun finansal yönetim üzerine etkisi [Impact of inflation on financial management]. Çukurova Üniversitesi İktisadi ve İdari Bilimler Fakültesi Dergisi, 6(1), 263-276.

Aksulu, İ. (1993). Tüketicinin sosyo-ekonomik ve demografik özellikleri ve marka seçimi davranışları üzerindeki etkileri [Socio-Economic and Demographic Characteristics of Consumers and their Effects on Brand Selection Behaviors]. İzmir: İlkem Ofset. 
Anbar, A., \& Eker, M. (2009). Bireysel yatırımcıların finansal risk algılamalarını etkileyen demografik ve sosyo-ekonomik faktörler [Demographic and socio-economic factors affecting financial risk perceptions of individual investors]. Zonguldak Karaelmas Üniversitesi Sosyal Bilimler Dergisi, 5(9), 129-150.

Armağan, S. (2007). Kar dağıtım politikalarının bireysel yatırımcı kararları üzerine etkileri ve bir uygulama [The effects of profit distribution policies on individual investor decisions and an application] (Unpublished master's thesis). Süleyman Demirel Üniversitesi Sosyal Bilimler Enstitüsü, Isparta: Turkey.

Bernstein, W. (2005). Yatırımın dört temel taşı [The four pillars of the investment]. (Translator: Neşenur Domaniç, Nusret Ayhan). İstanbul: Scala Publishing.

Bodur, Y. A. (2016). Yatırımcı davranışlarını etkileyen faktörlerin aşıı güven açısından değerlendirilmesi [Investigating factors that affect investor behavior in terms of over-reliance] (Project). Pamukkale Üniversitesi Sosyal Bilimler Enstitüsü İsletme Anabilim Dalı Muhasebe-Finansman Programı, Denizli: Turkey.

Cornicello, G. (2004). Behavioral finance and speculative bubble (Unpublished master's thesis). Universita Commercial Luigi Bocconi, Milano: Italy.

Demir, Y., Akçakanat, T., \& Songur, A. (2011). Yatırımcıların psikolojik eğilimleri ve yatırım davranışları arasındaki ilişki: IMKB hisse senedi yatırımc1ları üzerine bir uygulama [The relationship between investor psychological tendencies and investment behavior: An application on ISE stock investors]. Gaziantep Üniversitesi Sosyal Bilimler Dergisi, 10(1), 117 145 .

Doğan, M., Yıldız, F., \& Topal, Y. (2016). Yatırım tercihlerinin demografik özelliklere bağlı olarak değişmesi: türkiye'deki banka çalışanları üzerine bir uygulama [Change depending on the demographic characteristics of the investment preferences: an application on the bank's employees in turkey]. Journal of Accounting, Finance and Auditing Studies, 2(3), 185-199.

Döm, S. (2003). Yatırımcı psikolojisi [Investor psychology] (First Edition). İstanbul: Değişim Publishing.

Dwyer, P. D., Gilkeson, J. H., \& List, J. A. (2002). Gender differences in revealed risk taking: evidence from mutual fund investors. Economics Letters, 76(2), 151-158.

Ede, M. (2007). Davranışsal finans ve bireysel yatırımcı davranışları üzerine ampirik bir uygulama [Empirical application on behavioral finance and individual investor behavior] (Unpublished master's thesis). Marmara Üniversitesi Bankacilik ve Sigortacılık Enstitüsü, İstanbul: Turkey.

Elmas, B. (2010). Hisse senedi yatırımcılarının davranışsal özellikleri bireysel yatırımcıya yönelik bir araştırma [The behavioral characteristics of stock investors based on an individual investor-oriented research] (Unpublished doctoral dissertation). Atatürk Üniversitesi Sosyal Bilimler Enstitüsü, Erzurum: Turkey.

Fuller, J. R. (1998). Behavioral finance and source of alpha. Journal of Pension Plan Investing, 2(3), 1-22.

Gazel, S. (2014). Davranışsal finans psikolojik eşik ve önyargılar [Behavioral finance psychological thresholds and prejudices]. Ankara: Detay Publishing.

Gümüş, F. B., Koç, M., \& Agalarova, M. (2013). Bireysel yatırımcıların yatırım kararları üzerinde etkili olan demografik ve psikolojik faktörlerin tespiti üzerine bir çalışma: Türkiye ve Azerbaycan uygulaması [A study on the identification of effective demographic and psychological factors on the investment decisions of individual investors: Turkey and Azerbaijan app]. Kafkas Üniversitesi İktisadi ve İdari Bilimler Fakültesi Dergisi, 4(6), 71-93.

Hoffmann, A. O. I., Post, T., \& Pennings, J. M. E. (2013). Individual investor perceptions and behavior during the financial crisis. Journal of Banking and Finance, 37, 60-74.

Hon, T. Y. (2012). The behaviour of small investors in the Hong Kong derivatives markets: A factor analysis. Journal of Risk and Financial Management, 5, 59-77.

Hsu, C. H. C., Kang, S. K., \& Lam, T. (2006). Reference group influences among Chinese travelers. Journal of Travel Research, 44(4), 474-484.

İslamoğlu, M., Apan, M., \& Ayvalı, A. (2015). Determination of factors affecting individual investor behaviours: A study on bankers. International Journal of Economics and Financial Issues, 5(2), 531-543.

Jureviciene, D., Bikas, E., \& Gausiene, E. (10-11 May 2012). Behavioural finance during economic downturn in Lithuania. Paper presented at the 7th International Scientific Conference Business and Management, Vilnius.

Kahneman, D. (2002). Maps of bounded rationality: A perspective on intuitive judgment and choice. Nobel prize lecture, 8 , $351-401$.

Kahneman, D., \& Tversky, A. (1979). On the interpretation of intuitive probability: A reply to Jonathan Cohen. Cognition, 7(4), 409-411.

Kahyaoğlu, M. B. (2011). Yatırım kararlarına etki eden çeşitli duygusal ve psikolojik faktörlere maruz kalma düzeyi üzerinde cinsiyetin rolü: İMKB bireysel hisse senedi yatırımcıları üzerine bir uygulama [The role of gender on the level of exposure to various emotional and psychological factors affecting investment decisions: An application on the ISE individual stock investors]. Ekonomik ve Sosyal Araştırmalar Dergisi, 7(1), 29-51. 
Kalayci, S. ( 2010). SPSS applied multivariate statistical techniques. 5th Ed. Ankara, Turkey: Asil Yayin Dagitim.

Karan, M. B. (2004). Yatırım analizi ve portföy yönetimi [Investment analysis and portfolio management]. Ankara: Gazi Publishing.

Keklik, H. (2011). Davranışsal finans, 15.03.2018 Retrieved from http://halilkeklik.blogspot.com/2011/02/davranissalfinans-3finansal

Kesbiç, C. Y., \& Yiğit, M. (2016). Bireysel yatırım tercihlerinde risk faktörünün önemi: Manisa ili yatırımcı profili analizi [Advantages of risk factor in individual investment preferences: Analysis of investor profile in Manisa]. Finans Politik \& Ekonomik Yorumlar, 53(613), 79-94.

Lebbe, A., \& Rauf, A. (2014). Individual investor behaviour: Pre and post crisis study on Bahrain. Journal of Emerging Trends in Economics and Management Sciences (JETEMS), 5(5), 457-464.

Mishkin, F. S. (2010). The economics of money banking and financial markets. Boston: Addison-Wesley.

Nagy, R. A., \& Obenberger, R. W. (1994). Factors influencing individual investor behavior. Financial Analysts Journal, 50(4), 63-68.

Nofsinger, J. R. (2005). The psychology of investing (Second Edition). Pearson Education Hall.

Nyamute, W., Lishenga, J., \& Oloko, M. (2015). The relationship between investor behavior and portfolio performance at the Nairobi Securities Exchange. International Journal of Multidisciplinary Research and Development, 2(5), 548-551.

Özaltın, S., Ersoy, E., \& Bekçi, İ. (2015). Kar dağıtım politikasının bireysel yatırımcıların yatırım kararları üzerine etkisi [The effect of profit distribution policy on investment decisions of individual investors]. Süleyman Demirel Üniversitesi İktisadi ve İdari Bilimler Fakültesi Dergisi, 20(2), 397-411.

Perşembe, A. (2001). Teknik analiz mi dedin? hadi canım sen de [You mean technical analysis? Come on] (First Book). İstanbul: Scala Publishing.

Saraç, M., \& Kahyaoğlu, M. B. (2011). Bireysel yatırımcıların risk alma eğilimine etki eden sosyo-ekonomik ve demografik faktörlerin analizi [Analysis of socio-economic and demographic factors affecting the risk taking tendency of individual investors]. BDDK Bankacılık ve Finansal Piyasalar Dergisi, 5(2), 135-157.

Schaofer, H. (1993). Economic trend analysis for executives and investors. London: Quorum Books.

Sezer, D. (2013). Yatırımcı davranışlarının etkinliği ve psikolojik yanılsamalar [The effectiveness of investor behaviors and psychological illusions] (Unpublished doctoral dissertation). Adnan Menderes Üniversitesi Sosyal Bilimler Enstitüsü İşletme Anabilim Dalı, Aydın: Turkey.

Shefrin, H. (2001). Behavioral corporate finance. Journal of Applied Corporate Finance, 14(3), 113-124.

Shleifer, A. (2004). Does competition destroy ethical behavior? American Economic Review, 94(2), 414-418.

Temizel, F., Sarıkaya, M., \& Bayram, F. (2010). Yatırımcı ilişkileri yönetiminde iletişim ve bilgi teknolojilerinin rolü: İMKB 50 endeksi uygulamas1 [The role of communication and information technology in the management of investor relations: ISE 50 index application]. Atatürk Üniversitesi İktisadi ve İdari Bilimler Dergisi, 24(2), 1-20.

Thaler, R. H., \& Sunstein, C. R. (2017). Nudge: la méthode douce pour inspirer la bonne décision. Vuibert.

The Royal Swedish Academy of Sciences. (2002). Foundations of behavioral and experimental economics: Daniel Kahneman \& Vernon Smith. Advanced information on the Prize in Economic Sciences 2002, 1-25.

Tufan, E. (2006). Davranı̧sal finans [Behavioral finance]. Ankara: Orion Publishing.

Tufan, E. (2008). Davranışsal finans: Finansal kararları yönlendiren sosyal psikolojik anomalilerin davranışsal finans bağlamında incelenmesi ve imkb açısından değerlendirmesi [Behavioral Finance: An Analysis of Social Psychological Anomalies Directing Financial Decisions in the Context of Behavioral Finance and Evaluation in Terms of the ISE]. Ankara: İmaj Yayınevi.

Usul, H., Bekçi, İ., \& Eroğlu, A. H. (2002). Bireysel yatırımcıların hisse senedi edinimine etki eden sosyo-ekonomik etkenler [Socio-economic factors affecting the acquisition of stocks of individual investors]. Erciyes Üniversitesi İktisadi ve İdari Bilimler Fakültesi Dergisi, 19, 135-150.

Yeşildağ, E., Atasever, M., Kuduz, N., \& Coşkun, A. (2017). Afyonkarahisar ve Kütahya illerindeki hisse senedi yatırımcılarının profili ve yatırım kararlarını etkileyen faktörlerin analizi [Afyonkarahisar and Kütahya illusions of stock investors' analysis of the factors affecting the profile and investment decisions]. Akademik Sosyal Araştırmalar Dergisi, $5(53), 257-277$.

Yıldırım. H. (2017). Davranışsal finans yatırımcı davranışlarını esas alan modeller [Behavioral finance models based on investor behavior] (First Edition). İstanbul: Sokak Kitapları Publishing. 